\title{
NEWFOUNDLAND OFFSHORE CLAIMS
}

\author{
NOELA J. INIONS*
}

Both international law and constitutional law issues are involved in Newfoundland's claims to the natural resources lying off its coasts. Precedents from Canadian, British and Australian jurisprudence are examined to determine the likelihood of Newfoundland's establishing sovereignty or historical jurisdiction over its offshore resources.

\section{INTRODUCTION}

Offshore mineral rights have become increasingly important as the search for natural resources has turned to the last remaining frontier of the sea. The quantity of submerged hydrocarbons in the Newfoundland area has been estimated to be from 1 to 3.5 billion barrels of oil alone. ${ }^{1}$ In 1975 the Newfoundland Premier, Frank Moores, declared: ${ }^{2}$

We have oil, that's been proved. Every time they stick a well in the ground, it produces. The problem is getting control of it. It's our oil, but Ottawa wants it. If the Supreme Court of Canada decides against us, we will not accept the decision. We will secede from the Confederation, if necessary and come back in on our own terms. We don't need a lot of off shore oil and gas to satisfy the needs of our small popula. tion, but we want the first shot at what we have.

At that time Newfoundland was preparing to bring its case to the Supreme Court of Canada. ${ }^{3}$

The Maritime Provinces of Nova Scotia, New Brunswick, and Prince Edward Island signed an offshore agreement with the federal government on February 1, 1977, but Newfoundland found this unacceptable.4 In the meantime, Newfoundland has promulgated its own Regulations, ${ }^{5}$ which are significantly different from the proposed Canada Oil and Gas Act. ${ }^{6}$

When the Conservative government announced in September 1979 that it would grant full jurisdiction over offshore resources to the coastal provinces, the provincial efforts towards litigation were suspended. The fall of the Conservative government together with recent constitutional developments will likely encourage Newfoundland to place this matter before the Supreme Court of Canada. The current practice of oil companies engaged in offshore exploration off Newfoundland is to obtain both federal and provincial exploration permits. ${ }^{7}$

* Of the graduating class of 1982, Faculty of Law, The University of Alberta.

1. Oil \& Gas Journal, Nov. 10, 1980, 162 (1 billion); Department of Mines and Energy, Government of Newfoundland, The Province of Newfoundland and Labrador Offshore Petroleum Resources Review (unpublished, 1976) 17 (3.5 billion).

2. "Moores: If Necessary We Will Secede" (Sept. 29, 1975) Time Canada 11 at 13.

3. "Newfoundland: Last Harrumph" (Sept. 29, 1975) Time Canada 11 at 13.

4. Rowland Harrison, "The Offshore Mineral Resources Agreement in the Maritime Provinces" (1978) 4 Dal. L.J. 245; "Federal-Provincial Memorandum of Understanding in respect of the Administration and Management of Mineral Resources Offshore of the Maritime Provinces" signed February 1, 1977, by the Prime Minister of Canada and the Premiers of Nova Scotia, New Brunswick and Prince Edward Island.

5. The Newfoundland and Labrador Petroleum Regulations, N. Reg. 233/77, as am..

6. An Act to regulate the disposition and development of oil and gas rights, 3rd Sess. 30th Parl., 1977, Bill C-20 (H. of C.).

7. Joseph Ippolito, "Newfoundland and the Continental Shelf; From Cod to Oil and Gas" (1976) 15 Columbia J. Transnational Law 138 at 141. 
The Province of Newfoundland claims ownership of, and jurisdiction over, the mineral resources of its adjacent continental margin. ${ }^{8}$ The province claims that these minerals were vested in the Crown in Right of Newfoundland prior to Confederation. ${ }^{9}$ The ownership of the natural resources was not transferred to the federal government, but was expressly retained by the province in Term 37 of the Terms of Union. ${ }^{10}$ The legal claims of Newfoundland are sui generis as the historical circumstances of Newfoundland are distinguishable from all other offshore resources cases. ${ }^{11}$ It is the position of the writer that, despite the persuasive arguments on both sides, the weight of argument favours Newfoundland's ultimate success.

\section{JURISPRUDENCE}

\section{A. The British Columbia Precedent}

The leading Canadian decision concerning the offshore region is $R e$ Offshore Mineral Rights of British Columbia, a 1967 case heard on reference from the Governor-in-Council. ${ }^{12}$ This case arose as a result of both federal and provincial governments issuing conflicting offshore drilling permits and after an earlier attempt to settle this dispute had failed.13

The Supreme Court of Canada was asked five questions. ${ }^{14}$ The first three related to lands under the territorial sea: did British Columbia or Canada own this property, have the right to explore and exploit the natural resources, and have legislative jurisdiction? The last two questions related to the continental shelf: who had the right to explore and exploit the natural resources and who had legislative jurisdiction? The answer to all five questions, a unanimous judgment of a seven man bench, was Canada. ${ }^{15}$ This gave Canada exclusive jurisdiction over the mineral resources of both the territorial sea and the continental shelf as against British Columbia.

In relation to the territorial sea, British Columbia would retain ownership of all lands owned upon entry into Confederation in $1871 .{ }^{16}$ Based on the 1876 case of $R$. v. Keyn ${ }^{17}$ the Court held that the territory of British Columbia ended at the low water mark. Although the realm could be extended by the Crown in Right of the Colony of British Columbia to include the territorial sea, this required a legislative act by Parliament which had not occurred. ${ }^{18}$ Nor had Canada extended the boundaries of British Columbia after Confederation. ${ }^{10}$

8. "Newfoundland's Position on the Management of Energy Resources of the Continental Margin" presented to the National Energy Conference, Ottawa, January 22-23, 1974.

9. Cabot Martin, "Newfoundland's Case on Offshore Minerals: A Brief" (1975) 7 Ottawa L. Rev. 34; supra $\mathrm{n} .7$ at 140.

10. Schedule of Terms of Union of Newfoundland with Canada, British North America Act of 1949, 12 and 13 Geo. 6, c. 22 (Appendix II).

11. Supra n. 7 at $139 \cdot 140$.

12. Reference Re Ownership of Off-Shore Mineral Rights (1967) 65 D.L.R. (2d) 353 (S.C.C.).

13. Supra n. 7 at 141.

14. Supra n. 12 at $353-354$.

15. Id.

16. Id. at 359.

17. R. v. Keyn (1876-77) 2 Ex. D. 63 (P.C.).

18. Supra n. 12 at 367.

19. Id. at 366 . 
In relation to the continental shelf, the Court held that British Columbia had no legislative jurisdiction or right to explore and exploit, as the continental shelf was outside the boundaries of British Columbia, and Canada was the sovereign State recognized by international law. ${ }^{20}$ As the province had no rights in the territorial sea it would be illogical to find continental shelf rights.

Having decided that the territorial seabed did not belong to British Columbia, the Court proceeded to determine how and when Canada acquired ownership. The Court held that the rights which the British Crown had formerly exercised in right of the Colony of British Columbia were transferred to the Crown in Right of Canada at Confederation in 1871. ${ }^{21}$ The effect, in the opinion of the Supreme Court of Canada, of the Territorial Waters Jurisdiction Act, 1878 (U.K.). ${ }^{22}$ was that the United Kingdom claimed jurisdiction over the territorial sea in respect of the Dominion of Canada. ${ }^{23}$ When Canada achieved sovereignty, between the Treaty of Versailles in 1919 and the Statute of Westminster in 1931, it was able to assert sovereignty over the resources of the territorial sea and continental shelf as international law allowed. ${ }^{24}$

It is interesting to note that the Court cites the Territorial Waters Jurisdiction Act, 1878 (U.K.) as showing that property to the seabed had vested in the Crown, when in fact ownership is not provided for in the Act. ${ }^{25}$ Also, although the Geneva Convention does provide for the extension of sovereignty over the territorial sea as well as to the seabed and subsoil, at the time of the decision it had not been ratified by Canada. ${ }^{26}$

The territorial sea is defined in the Territorial Sea and Fishing Zones Act ${ }^{27}$ and means the sea and submerged lands which extend from the low water mark to three nautical miles seaward. A coastal nation is said to have "sovereignty" over its territorial sea which includes the right to property (ownership), the right to exploit and explore for natural resources, and legislative jurisdiction. ${ }^{28}$ The continental shelf was defined at the Geneva Convention, 1958 (Appendix 1) ${ }^{20}$ and refers to the seabed and subsoil (not seas) extending from the territorial sea to either a depth of 200 metres or as far as natural resources are exploitable. A coastal nation has "sovereign rights" over the continental shelf which only include legislative jurisdiction and the specific right to exploit and explore for natural resources. ${ }^{30}$

20. Id. at 380.

21. Id. at 373 .

22. (U.K.), 41 and 42 Vict., c. 73.

23. Supra n. 12 at 374.

24. Id. at 375.

25. Rowland Harrison, "Jurisdiction Over The Canadian Offshore: A Sea of Confusion" (1979) 17 Osgoode Hall L.J. 469 at 481.

26. Id.

27. The Territorial Sea and Fishing Zones Act, 1964, S. C. 1964, c. 22, s. 3 (1); Substituted by R.S.C. 1970, c. T-7, s. 3(1), as am., R.S.C. 1970, (1st Supp.), c. 45, s. 3(1).

28. U.N. Doc. A CONF. 13 L. 52, adopted April 27, 1958, The Convention on the Territorial Sea and Contiguous Zone, adopted at 1958 Geneva Convention.

29. U.N. Doc. A CONF. 13 L. 55, adopted April 26, 1958; Convention on the Continental Shelf, adopted at 1958 Geneva Convention, Article I; see Appendix I.

30. Id. at Article 2, Paragraph 1; K. Beauchamp et al, "Jurisdictional Problems in Canada's Offshore" (1973) 11 Alta. L. Rev. 431 at 433. 
Prime Minister Trudeau later referred to the opinion in the British Columbia Reference case as "an authoritative clarification of the legal position ... . on the basis of principles that would appear to be substantially applicable to the east coast as well as to the west coast ..." ${ }^{31}$ The east coast provinces argue that although these principles may apply, their application will lead to a different result by virtue of their different histories ${ }^{32}$ This is particularly true of Newfoundland which, as well as denying the correctness of the British Columbia Reference, has publicly relied on its former status as a sovereign dominion as a basis for insisting that the ratio decidendi in this case would yield a different result if applied to Newfoundland.

B. R. v.Keyn

The keystone of the reasoning of the Court in the British Columbia Reference case was the majority decision in $R$. v. Keyn.$^{33}$ The commander of the Franconia, a foreign ship, was indicted for manslaughter before the Central Criminal Court of England. A plea of jurisdiction was entered by the accused, who argued that as the offence was committed in territorial waters (within three miles of Dover), it was outside the realm of the United Kingdom. The majority of the Court held that the British courts had no jurisdiction as the territory of England ends at low water mark.

The Keyn majority acknowledged that this jurisdiction could be enlarged, but only by an act of Parliament. ${ }^{34}$ The Territorial Waters Jurisdiction Act (U.K.) was promptly passed to bring acts committed in the territorial sea by foreign ships under the jurisdiction of the admiral..$^{35}$

The Keyn case is characterized by an extreme conflict of judicial opinion. The Privy Council has frequently commented on the confusion apparent in the Keyn decision. ${ }^{36}$ Indeed the Chelikani case appears to overrule Keyn and hold that the seas inherently belong to the King, both in governorship and proprietorship. ${ }^{37}$ The recent Australian decisions generally accept Keyn as interpreted in the British Columbia Reference, but powerful dissents exist. ${ }^{38}$ The total acceptance of Keyn by the Supreme Court of Canada in the British Columbia Reference case is curious in view of the surrounding controversy as to what the ratio decidendi even is. ${ }^{39} R$. v. Keyn was heard by an unusual number of judges (fourteen), one of whom died before judgment was rendered, and decided by a narrow majority (7:6).

31. Statement On Offshore Mineral Rights by the Prime Minister in the House of Commons, Dec. 2, 1968.

32. Supra n. 25 at $\mathbf{4 7 0 .}$

33. Supra n. 17.

34. Id. at 804.

35. Supra n. 22.

36. A.G. British Columbia v. A.G. Canada (1889) 14 A.C. 295; Pianka v. The Queen [1977] 3 W.L.R. 859: Secretary of State for India in Council v. Chelikani Rao (1916) L.R. 43 Ind. App. 192, 199; 32 T.L.R. 652, 653; 8 S.L.J.P.C. 222 (Referred to as the Chelikani case hereafter).

37. Id. (Chelikani case).

38. New South Wales v. Commonwealth (The Seas and Submerged Lands Case) (1975) 135 C.L.R. 337; 8 A.L.R. 1, at 12 (A.L.R.); Bonser v. LaMacchia (1969) 122 C.L.R. 177, 1969 A.L.R. 741 at 744 (A.L.R.); R. v. Bull (1974) 131 C.L.R. 203, 48 A.L.J.R. 232, at 219 (C.L.R.).

39. Supra n. 25 at 473. 


\section{Australia}

The Australian counterpart of the British Columbia Reference is New South Wales v. Commonwealth (The Seas and Submerged Lands case), ${ }^{10}$ a 1975 High Court case. The Court held that the boundaries of the States end at low water mark and that no proprietary rights in respect to the territorial sea or continental shelf accrue. ${ }^{41}$ The enactment of the Seas and Submerged Lands Act, $1973^{42}$ was found to be a valid exercise of Commonwealth jurisdiction in respect to "external affairs".

Jacobs J. for the majority in the Seas and Submerged Lands case, rejected the majority view of Keyn and adopted the Chelikani case wherein it was held that the seas belonged to the King. Jacobs J. felt that the dominion and proprietorship of the King had not been transferred to the Australian colonies, so that no part of the sea referred to in the Act adhered to the Australian states. ${ }^{43}$

Mr. Justice Jacobs believed that Keyn was right in holding that the common law did not extend beyond the low water mark, and that dominion and proprietorship were a Crown prerogative which were not limited by the common law. ${ }^{4}$ It is apparent that the reasoning of Jacobs J. raises the possibility of leaving the result of the British Columbia Reference undisturbed, but permitting the Supreme Court of Canada to accept contrary authorities to Keyn such as the Chelikani case.

\section{Maritime Provinces}

The position of the other Atlantic Provinces can also be distinguished from the position of British Columbia. The early commissions in Nova Scotia defined the boundaries to include "appurtenances thereunto belonging" and to the centre of the Bay of Fundy. ${ }^{45}$ Nova Scotia exercised territorial sea jurisdiction in hovering legislation. ${ }^{46}$ In the Dominion Coal case, ${ }^{47}$ Chief Justice Isley found that a submarine mine within three miles of the Nova Scotia coast was not assessable by Cape Breton County, despite his assumption that Nova Scotia owned the coal itself. ${ }^{48}$

New Brunswick also exercised pre-Confederation offshore jurisdiction in the three mile territorial zone by the use of hovering legislation..$^{8}$ The Supreme Court of New Brunswick in Rex v. Burt ${ }^{50}$ found that jurisdiction existed in relation to a schooner laden with liquor that was one and three quarter miles from shore. Mr. Justice Baxter felt that these were internal waters by virtue of express provisions and also that New Brunswick enjoyed

40. Supra n. 38 (New South Wales).

41. Id. at 111 A.L.R. .

42. No. 161 of 1973.

43. Supra n. 38 at 17 A.L.R.; Supra n. 25 at 477.

44. Supra n. 38 at 104 A.L.R.

45. Description supplied by the Department of the Attorney General of Nova Scotia; officials to G. LaForest; Natural Resources and Public Property Under the Canadian Constitution (1969) 86; Royal Commission to Lord Elgin, Sept. 1/1846; Id. at 87.

46. 1770 (N.S.), 10 Geo. III, c. 10 - Fish Offal; 1836 (N.S.), 6 Wm. IV, c. 8.

47. Re: Dominion Coal Co. Ltd. and County of Cape Breton (1963) 40 D.L.R. (2d) 593.

48. Id. at 601.

49. (N.B.), 16 Vict., c. 39, s. 5, May 3, 1853; R.S.N.B. 1854 , c. 101 , s. 6.

50. Rex v. Burt (1932) 5 M.P.R. 112. 
rights in the three mile region. ${ }^{51}$ Prince Edward Island also enacted preConfederation hovering legislation in the three mile limits2 $^{52}$ and was given "adjacent territories" by commission..$^{53}$

Clearly the Court in the British Columbia Reference was aware of the fact that some of the colonies had exercised legislative jurisdiction and proprietary rights in the territorial sea prior to Confederation..$^{54}$ How then can the actual exercise of these rights be reconciled with the view that jurisdiction over, and ownership of, the bed of the territorial sea did not adhere to the colonies?

\section{NEWFOUNDLAND}

\section{A. Sovereignty}

Perhaps the most crucial aspect of Newfoundland's claim is proving preConfederation sovereignty. This could entitle Newfoundland to rights in the territorial sea and the continental shelf, by distinguishing the situation of Newfoundland from that of British Columbia. Sovereignty before 1949 would render much of the reasoning in the British Columbia Reference favourable to Newfoundland.

Judicial authority is sparse on the attributes of a sovereign state. Anobiter remark made in the Duff Development case by Viscount Finlay is helpful: ${ }^{55}$

It is obvious that for sovereignty there must be a certain amount of independence, but it is not in the least necessary that for sovereignty there should be complete independence. It is quite consistent with sovereignty that the sovereign may in certain respects be dependent upon another power: the control for instance, of foreign affairs may be completely in the hands of a protecting power, and there may be agreements or treaties which limit the powers of the sovereign even in internal affairs without entailing a loss of the position of a sovereign power.

To ascertain whether sovereignty existed in Newfoundland before its union with Canada, it is essential to delve into the intricacies of Newfoundland history.

This "certain amount of independence" may have arisen by Newfoundland's exercise of full control over internal affairs ${ }^{56}$ and some degree of influence over foreign affairs ${ }^{57}$ by the mid-nineteenth century. Theoretically at least, Newfoundland reached the status of a sovereign dominion by virtue of the Report of the Inter-Imperial Relations Committee to the Imperial Conference of $1926,^{58}$ which declared to the world that the Dominions had reached the status of equal sovereign states. The status of dominion was explicitly given to Newfoundland by the Statute of Westminster, $1931,{ }^{69}$ which is generally conceded to be declaratory (rather than constitutive) of constitutional status. ${ }^{60}$

51. Id. at 117.8 .

52. (P.E.I.), 6 Vict., c. 14, 1843.

53. Quoted in LaForest, supra n. 45 at 87 - Commission to Governor Patterson.

54. Supra n. 25 at 505.

55. Duff Development Co. Ltd. v. Government of Keltan [1924] A.C. 979 (H.L.).

56. G. Chadwick, Newfoundland: Island Into Province (1967) 15.

57. Id. at 35 ; supra n. 9 at 39.

58. Imperial Conference, Summary of Proceedings, CMD 2768, 15, 13-30 (1926).

59. Statute of Westminster (U.K.), 22 and 23 Geo. 5, c. 4.

60. A. Kovach, "An Assessment of the Merits of Newfoundland's Claim To Offshore Mineral Resources" (1975) 23 Chitty's Law J. 18 at 19; supra n. 7 at 154; supra n. 9 at 39. 
Newfoundland's dominion status by this time was reflected in internal legislative enactments which established a High Commissioner in London ${ }^{61}$ provided a national flag, ${ }^{62}$ altered the title of Colonial Secretary to Secretary of State, ${ }^{63}$ and created a Department of External Affairs. ${ }^{64}$ Although Newfoundland did not fully implement its foreign affairs powers, some degree of extraterritorial sovereignty was exercised, especially in relation to the United Kingdom and Canada. ${ }^{65}$

It has been suggested that Newfoundland did not become a true dominion because Newfoundland chose not to apply certain sections of the Statute of Westminster. ${ }^{66}$ This arrangement was no more derogatory to Newfoundland's sovereignty than the current Canadian situation with the B.N.A. Act continuing to be a part of an Act of the Parliament of the United Kingdom, preventing Canada from amending that Act. ${ }^{67}$ The important factor is that the preamble of the Statute of Westminster recognized Newfoundland's status as an independent and sovereign Dominion without reference to the Imperial Crown. ${ }^{68}$

Newfoundland reached a desperate financial position during the early 1930 ' ${ }^{69}$ and upon the recommendation of the Amulree Royal Commission, the Letters Patent were suspended. ${ }^{70}$ Commission Government was instituted from 1934 to 1949 . Was sovereignty revoked during this period?

It has been argued that sovereignty was not lost as this was merely a financial/administrative change in government, not the secession of sovereign status. ${ }^{71}$ The presumption against the giving up of sovereignty ${ }^{72}$ presumes that only those powers expressly transferred are given up, entailing only "the administration of the Island"73 here. International law is committed to the continuing sovereignty of territorial communities, and the surrender of sovereignty is interpreted strictly, as upheld in France v. United States of America, ${ }^{74}$ and the Kelantan ${ }^{75}$ and Johore ${ }^{76}$ cases.

61. High Commissioner's Act, 1921 (Nfld.), 12 Geo. 5 , c. 6.

62. An Act to Provide A National Flag for Newfoundland and Colours to be Worn By Vessels, 1931 (Nfld.), 22 Geo. 5 , c. 3.

63. An Act to Alter the Title of the Colonial Secretary, 1931, 22 Geo. 5, c. 10.

64. An Act Relating to the Department of External Affairs, Nfld. Stat. 1931, c. 14.

65. Newfoundland entered into several international agreements, e.g. Postal Convention with Newfoundland, Feb. 10, 1926, 44 Stat. 2353 (1925-27). For many more see supra n. 7 at 154.

66. Supra n. 60 at 19.

67. British North America Acts, 1867 to 1930, s. 7, depriving Canada of full benefit of $\mathrm{s} .2$ (2) to repeal/amend the United Kingdom Act as it applies to the Dominion of Canada.

68. Id. Preamble.

69. John Parker, M.P., Newfoundland - 10th Province of Canada at 25 as cited in Kovach, supra n. 60 at 19.

70. Royal Warrant of Feb. 17, 1933, in Newfoundland Royal Commission Report, CMD. No. 4480, at ii (1933), Address to the King, Nfld. Stat. 2nd Sess., 1933.

71. Supra n. 9 at 40-41; Canada has also recognized Newfoundland's sovereignty by the maintenance of a High Commissioner in Newfoundland right up to the date of Union, thus recog. nizing a relationship not possible with a colony and maintained only with the U.K. and other Dominions.

72. Supra n. 9 at 41.

73. Supra n. 70.

74. France v. United States of America (Case Concerning Rights of United States of America in Morocco) (1952) I.C.J. 176.

75. Supra n. 55.

76. Mighell v. Sultan of Johore [1894] 1 Q.B. 149 (CA). 
Others argue that sovereignty was lost during the period of Commission Government. Colin Douglas feels that the island had "no independence at all"77 and that the requirement of some degree of independence was not met. ${ }^{78}$ The Attorney General of Britain stated that although in name a dominion, Newfoundland was actually a colony with the United Kingdom enjoying complete sovereignty. ${ }^{79}$

Term 7 of the Terms of the Union stated that the pre-1934 constitution was revived and continued to be the Constitution of Newfoundland. ${ }^{80}$ It has been argued that the effect of Term 7 is only to specify which legal document serves as the constitution of the new province. ${ }^{.1}$

Other commentators argue that Term 7 expressly revived the pre-1934 constitution of Newfoundland prior to the Terms of the Union taking effect. Louis St. Laurent, then Prime Minister, explained that the significance of Term 7 was that the constitution was revived an instant before union became effective because of an Act of the United Kingdom agreeing to this arrangement. ${ }^{82} \mathrm{~A}$ major issue in the 1948 referenda campaigns was the fear of loss of constitutional rights upon Confederation with Canada ${ }^{83}$ Newfoundland was repeatedly told that formally returning to her pre-1934 status before Confederation would not improve her position. ${ }^{84}$ To deny the return of sovereignty before union would imply that Newfoundland was enticed by misrepresentation to enter Confederation, a position which the federal government is morally estopped from taking. ${ }^{85}$

It is submitted that Newfoundland achieved sovereignty at least by 1931 , as evidenced by the preamble to the Statute of Westminster. It is further submitted that sovereignty was not revoked during Commission Government as the requirement of "a certain amount of independence" was surely met. Even if sovereignty was lost during Commission Government, it is submitted that the effect of Term 7 was to expressly revive the pre-1934 constitution and restore sovereignty to Newfoundland before Confederation with Canada. It is crucial to Newfoundland's claims to the territorial seas and continental shelf that a sufficient degree of sovereignty can be established prior to Confederation.

\section{B. Historical Jurisdiction}

Even if Newfoundland were found to be sovereign, the courts would still look for evidence that the jurisdiction of the coastal state had been extended to the territorial sea prior to Confederation so that the province might continue to enjoy that jurisdiction. ${ }^{86}$ The problem with British Columbia's

77. Colin Douglas, "Conflicting Claims to Oil and Natural Gas Resources off the Eastern Coast of Canada" (1980) 18 Alta. L.R. 54 at 65.

78. Supra n. 55.

79. 462 Parl. Deb. H.C. (5th Sess.) 1265, 1266 (1949).

80. Supra n. 10 at Term 7 (Appendix II).

81. Supra $\mathrm{n} .7$ at $160-161$.

82. 1 H.C. Deb. 364 (1949).

83. Supra n. 9 at 42.

84. Id..

85. Id.; 462 Parl Deb. H.C. (5th Sess.) 1262 (1949).

86. Supra n. 4. 
claim was that it was unable to establish an extension of its jurisdiction prior to 1871 . Since the British Columbia Reference was based on the unique historical situation of British Columbia rather than strictly upon legal principles, it is cogent to examine the historical jurisdiction of Newfoundland in assessing this claim. ${ }^{87}$

The early territories claimed by the Imperial Crown in Right of the Colony of Newfoundland related specifically to land areas and would appear to exclude any offshore territory. ${ }^{88}$ Judicial decisions of pre-Confederation Newfoundland recognize extensions of jurisdiction over the territorial sea. In the 1875 case of Anglo-American Telegraph Co. v. Direct United States Cable Co. ${ }^{89}$ Chief Justice Hoyles of the Newfoundland Supreme Court held that Newfoundland could exercise jurisdiction more than three miles from shore within Conception Bay. ${ }^{90}$ On appeal, the Privy Council affirmed this decision and noted that by Imperial legislation, Great Britain had asserted dominion over the bay and had granted Newfoundland jurisdictional rights. ${ }^{91}$ This case was very narrowly interpreted in the British Columbia Reference, which alleged that the Imperial Legislature had only given Newfoundland the right to legislate in relation to Conception Bay and did not confer any general delegation powers with respect to the territorial sea. ${ }^{92}$

In Rhodes v. Fairweather, ${ }^{93}$ an 1888 Newfoundland Supreme Court case, it was held that Newfoundland did not have jurisdiction over the slaughter of seals beyond the three mile limit. Chief Justice Carter found that the jurisdiction of the courts of Newfoundland extended only three miles from shore. ${ }^{94}$ Rhodes was confirmed by an assessment of the Law Officers on December 27, 1888. ${ }^{95}$ The Newfoundland Supreme Court in the 1889 case of The Queen v. Delephine $e^{\theta 6}$ found that Newfoundland jurisdiction did not extend to offenders of the Newfoundland Bait Act when outside of the three mile limit, but did extend within this limit. ${ }^{97}$

Newfoundland began, in 1893 , to enact hovering legislation exercising jurisdiction within and beyond the three mile limit. Legislation affecting

87. George Swan, 'The Newfoundland Offshore Claims; Interface of Constitutional Federalism and International Law" (1976) 22 McGill L.J. 541 at 545.

88. Supra n. 10 at 3; Commission for James Webb of May 6, 1760; Commission to John Byron of May 13, 1769.

89. Anglo-American Telegraph Co. v. Direct United States Cable Co. (1875) 6 Nfld. L.R. 28.

90. Id. at 33.

91. Direct United States Cable Co. v. Anglo-American Telegraph Co. (1877) 2 A.C. 394, 420 (P.C.).

92. Supre n. 12 at 368.

93. Rhodes v. Fairweather (1888) 7 Nfld. L.R. 321.

94. Id. at 325-326.

95. Quoted by D.P. O'Connell, "Australian Coastal Jurisdiction" in International Law in Australia (D.P. O'Connell ed. 1966) 246, 277, citing C.O. Law Officer's Opinions, vol. iv, no. 134.

96. The Queen v. Delephine (1889) 7 Nfld. L.R. 378.

97. Id. at 386. 
territory within the three mile limit included the Foreign Fishing Vessels Acts $^{98}$ of 1893,1905 , and 1906 and the Customs Acts ${ }^{9 \theta}$ of 1898 and 1933. Legislation affecting territory beyond the three mile limit included the Oyster Fisheries Act of $1916^{100}$ and The Crown Lands Acts ${ }^{101}$ of 1903 and 1930, which respectively regulated "banks" and "mining sites beneath the sea or public tidal waters". This historical survey indicates that Newfoundland frequently asserted judicial and legislative jurisdiction over the territorial seas, and to a lesser extent beyond the territorial seas.

Much divergence of opinion exists in relation to whether Imperial legislation is necessary to legitimize Newfoundland's claim and whether this in fact occurred. The Keyn principle as interpreted in the British Columbia Reference requires that any extension of the realm beyond low water mark must be accomplished by an Act of Imperial Parliament. ${ }^{102}$ Kovach feels that this legislation must occur both during the period of colonial or non-sovereign status and by an Act of the former colony during the time it enjoys dominion or sovereign status. ${ }^{103}$ Kovach feels that this test is not satisfied and that due to this crucial defect, Newfoundland's claim fails. ${ }^{104}$ Ippolito believes that Newfoundland's boundary extensions were never formally legitimized by Imperial Parliament and that it is unlikely that Newfoundland will be exempted from the Keyn requirement. ${ }^{105}$ Martin emphasizes that the Imperial Crown clearly transferred jurisdictional competences of all types and all sovereign and property rights. ${ }^{106}$ Legislation such as the Agreement on Defence Installations in Newfoundland ${ }^{107}$ may overcome the Keyn problem regarding Imperial legislation.

It is the submission of the writer that sufficient Imperial legislation was enacted to satisfy the Keyn requirement. Alternatively, it is submitted that the Chelikani case is a more recent Privy Council decision that in effect overruled Keyn, making Imperial legislation unnecessary to establish legislative jurisdiction.

\section{INTERNATIONAL LAW ISSUES}

As international law regulates rights between nations, Newfoundland must either establish an Imperial statute granting rights over the continen-

98. An Act respecting Foreign Fishing Vessels, 1893 (Nfld.), 56 Vict., c. 6, s. 2; An Act respecting Foreign Fishing Vessels, 1905 (Nfld.), 5 Edw. VII, c. 4, s. 1; An Act respecting Foreign Vessels, 1906 (Nfid.), 6 Edw. VII, c. 1.

99. The Customs Act, 1898 (Nfld.), 61 Vict., c. 13; The Customs Act, 1933 (Nfld.), 21 Geo. 5, c. 15 , s. 168 (1).

100. Of the Propagation and Protection of Oysters, C.S.N. 1916, c. 165.

101. The Crown Lands Act of 1903 (Nfld.), 3 Edw. 7, c. 6, s. 49(1); The Crown Lands Act of 1930 (Nfld.), 21 Geo. V., c. 16, s. 168.

102. Supra n. 12 at 367.

103. Supra n. 60 at 22.23 .

104. Id. at 20-23.

105. Supra n. 7 at $146-147$.

106. Supra n. 9 at 37.

107. The Agreement on Defence Installations in Newfoundland, May 3, 1946, [1946] Can. T.S. No. 15, at 3, signed by Canada, Newfoundland, and the United Kingdom, which expressly extended to the undefined territorial waters of Newfoundland; it perhaps constitutes a recognition of Newfoundland sovereignty over its territorial sea. This recognition would overcome the Keyn problem with respect to waters lying within three miles of the shore. 
tal shelf or sovereignty before a contest arises between Canada and preConfederation Newfoundland rights. If Newfoundland was found to retain sovereignty up to 1949 , then unlike the other Canadian provinces which entered Confederation much earlier, it can utilize developments in the law of the sea. Newfoundland can attempt to establish that as a sovereign nation in 1949 , the right to exploit and explore the resources of the continental shelf was acquired under international law.

Continental shelf rights arising under international law are based on the continental shelf doctrine,$^{108}$ which declares that a coastal state has the exclusive right to exploit and explore the natural resources under the continental shelf adjacent to its landmass. These rights appear to be restricted to the specific purpose of exploiting and exploring for natural resources, and legislative jurisdiction. ${ }^{100} \mathrm{~A}$ broader concept of ownership relating to title and property in the subsoil or seabed, water, or airspace does not exist in relation to continental shelf rights as defined by the Geneva Convention, 1958..$^{110}$

Two divergent points of view exist in respect to when continental shelf rights arise. One side argues that continental shelf rights existipso facto and $a b$ initio from the time that a state becomes sovereign. The opposing side argues that continental shelf rights only arise when they become a rule of customary international law.

\section{A. Ab Initio Continental Shelf Rights}

If continental shelf rights are found to exist $a b$ initio, Newfoundland would only have to prove her pre-Confederation sovereignty to succeed, and the scope of jurisdiction exercised would be irrelevant. ${ }^{11}$ One proponent of this view is Cabot Martin, who asserts that as continental shelf rights prevail ipso facto and $a b$ initio an historical review of continental shelf claims is not necessary. ${ }^{112}$ This opinion is based upon the majority decision of the International Court of Justice in the North Sea Continental Shelf cases. ${ }^{113}$ The I.C.J. stated that it entertained no doubt about what it considered to be:114

.. . the most fundamental of all rules of law relating to the continental shelf, enshrined in Article 2 of the 1958 Geneva Convention, although quite independent of it, - namely that the rights of the Coastal State in respect of the area of continental shelf that constitutes a natural prolongation of its land territory into and under the sea exist ipso facto and $a b$ initio, by virtue of its sovereignty over the land, and as an extension of it in an exercise of sovereign rights for the purpose of exploring the seabed and exploiting its natural resources. In short, there is here an inherent right.

This judgment dealt with a controversy in relation to continental shelf rights which existed in the 1940's and 1950's, and would appear to have the effect of retroactively curing doubts in relation to rights of jurisdiction and exploitation. Although the application of a 1969 decision retroactively to 1949 appears absurd, retroactivity becomes a logical necessity if the statements of the Court that the shelf is a "natural prolongation" of coastal state territory, and that rights exist "ipso facto and $a b$ initio", are accepted. ${ }^{115}$

108. Supra n. 77 at 55.

109. Supra n. 30.

110. Geneva Convention, 1958, Articles 1-2 (Appendix I).

111. Supra n. 7 at 558 ; supra n. 9 at 36.

112. Supra n. 9 at 35.

113. North Sea Continental Shelf Cases [1969] I.C.J. 3.

114. Id. at 10.

115. Supra n. 7 at 151. 
Chief Justice Barwick of the High Court of Australia in Bonser v. LaMacchia ${ }^{116}$ accepted that the continental shelf appertains naturally to a nation as an international person. Dr. Daniel O'Connell, a leading international law scholar, understood that continental shelf rights obtain ipso facto, and that no special legal process or acts need be performed. ${ }^{117}$ His opinion was based upon the proceedings of the International Law Commission meeting of July $14,1950 .{ }^{118}$ Hersch Lauterpacht also supported the theory that an inherent right to exercise sovereignty over the continental shelf contiguous to its shore exists in a coastal state. ${ }^{119}$

Under this point of view there is no reason to ascertain a "crystallization" date at which continental shelf rights arose. It is important to note that the Supreme Court of Canada in the British Columbia Reference did not have the benefit of the decision of the International Court of Justice.

\section{B. Rule of Customary International Law}

Other scholars believe that continental shelf rights arise only by rule of customary international law. Under this assertion, Newfoundland must prove that by 1949 a coastal state had by international law the exclusive right to exploit the natural resources of the continental shelf, or the claim is lost, regardless of sovereignty. Canada argues that this right was not recognized at international law until Newfoundland became a province, and that when these rights accrued, they accrued to Canada as the coastal sovereign state.

The following are the traditional requirements for the existence of a rule of customary international law: ${ }^{120}$

(a) Concordant practice by a number of states with reference to a type of situation falling within the domain of international relations;

(b) Continuation or repetition of the practice over a considerable period of time;

(c) Conception that the practice is required by, or consistent with, prevailing international law; and

(d) General acquiescence in the practice by other states.

These requirements are imprecise at best, and involve an historical analysis of the development of the law.

Originally the bed and surface of the high seas were incapable of occupation by any state at international law. ${ }^{121}$ The $A b u$ Dhabi Arbitration case $^{122}$ was concerned with whether the Sheikh of Abu Dhabi had the right to win oil from submarine areas beyond the territorial waters. Lord Asquith

116. Bonser v. LaMacchia (1968-69) 122 C.L.R. 177 at 187.

117. D.P. O'Connell, International Law (1965) 578.

118. U.N. Doc. A/CN.4/SR.68, p. 13, para. 37.

119. Hersch Lauterpacht, "Sovereignty Over Submarine Areas"(1950)27 Brit. Y.B. Int IL. 376, 381 at 415-31.

120. Z. Slouka, International Custom and the Continental Shelf (1968) 41.

121. C. Colombos, The International Law of the Sea (5th ed. 1962) 63.

122. Petroleum Dev. (Trucial Coast)Ltd. v. The Sheikh of Abu Dhabi (1952)Int. and Comp. L.Q. 247. 
pointed out the unsettled nature of international law at that time. ${ }^{123}$ The Supreme Court of Canada in the British Columbia Reference held that by virtue of this case, the legal doctrine of the continental shelf did not exist in $1939 .{ }^{124}$

The first legal act claiming rights over zones under the high seas occurred in a "Treaty Relating to the Submarine Areas of the Gulf of Paria" of February 26, 1942, wherein Great Britain (on behalf of Trinidad and Tobago) and Venezuela each annexed certain parts of the Gulf of Paria. ${ }^{125}$ The continental shelf was not mentioned and the status of the waters and airspace was expressly reserved.

The Truman Proclamation of September 28, 1945 claimed the subsoil and seabed of the continental shelf in relation to the natural resources contiguous to the coasts of the United States as subject to its jurisdiction and control. ${ }^{126}$ It has been argued that by virtue of this claim and that of Britain, the two great marine nations recognized and supported the continental shelf doctrine by 1945. ${ }^{127}$ The Truman Proclamation was followed by a complex series of proclamations, decrees, and technical developments. ${ }^{128}$

The rights that a coastal state may exercise over the continental shelf are clarified in the 1958 Geneva Convention. ${ }^{129} \mathrm{It}$ is not clear whether the Convention was merely declaratory of a rule of customary international law or was constitutive of a new rule. ${ }^{130}$ This Convention came into force on June $10,1964 .{ }^{131}$ Although this Convention has been signed by Canada, it has not been ratified to date. ${ }^{132}$

The proposition that continental shelf rights accrue $a b$ initio was refuted to some extent by Gibbs J. in New South Wales v. Australia, ${ }^{133}$ who stated: ${ }^{134}$

Those rights, if theoretically inherent in the sovereignty of coastal states, were in fact the result of the operation of a new legal principle .... To say the rights of coastal states in respect of the continental shelf existed from the beginnings of time may or may not be correct as a matter of legal theory.

The opinions among writers as to when the continental shelf doctrine became a rule of customary law vary. Waldock did not believe that this doctrine had become a part of international law by $1950 . .^{135}$ Colin Douglas believes that this doctrine was not a customary rule of international law when Newfoundland joined Canada in Confederation. ${ }^{136} \mathrm{He}$ argues that

123. Id. at 255.

124. Supra n. 12 at 376.

125. [1942] Gr. Brit. T.S. No. 10 (Cand.) 6400.

126. Presidential Proclamation 2667 (Sept. 28, 1945) With Respect to Natural Resources of the Subsoil and Seabed of the Continental Shelf (1945) 10 Fed. Reg. 12303.

127. Supra n. 7 at 149 ; supra n. 12 ; supra n. 87 at 555 ; supra n. 113 at 33.

128. Supra n. 77 at $59-61$.

129. United Nations, United Nations Conference on the Law of the Sea U.N. Doc. A CONF. $13 / \mathrm{L} .55$ (1958) in Z. Slouka, International Custom and the Continental Shelf (1968) 41 at 89.

130. Supra n. 77 at $60-61$.

131. Supra n. 120 at 90.

132. Supra n. 30 at 432.

133. Supra n. 38 (New South Wales) at 337.

134. Id. at 416.

135. Supra n. 7 at 150.

136. Supra n. 77 at 62-63. 
although there may have been concordant proclamations and declarations by a significant number of states before March 1949, there had been no concordant practice before this time, either by wells drilled beyond the three mile limit or by proclamation. ${ }^{137}$ Douglas believes that this is the crucial defect in Newfoundland's claim, and that for this reason Canada would succeed.

Both Slouka ${ }^{188}$ and Hersch Lauterpacht ${ }^{139}$ write that this doctrine had become a part of international law by 1950. Cabot Martin feels that there are many strong arguments that this doctrine had been accepted by the nations of the world by 1949.140

Even if Newfoundland successfully establishes that the continental shelf doctrine was a rule of customary law by March 1949, one obstacle remains. Whereas the continental shelf doctrine refers only to the continental shelf, Newfoundland claims the entire continental margin composed of shelf, slope, and part of the rise. ${ }^{141}$ Newfoundland must either show that the original doctrine contemplated the entire continental margin in 1949, or restrict its claim to the physical continental shelf alone..$^{142}$

It is submitted that continental shelf rights exist ipso facto and arise $a b$ initio by virtue of the International Court of Justice's authoritative decision in the North Sea Continental Shelf cases. If these rights are found to arise only by rule of customary international law, it is submitted that these rights were recognized in international law by 1949 by virtue of the Gulf of Paria Treaty and the Truman Proclamation. In either event, Newfoundland, as a sovereign coastal state, acquired continental shelf rights before Confederation with Canada, so Newfoundland's claim in this area will likely be successful. However, the claim to the entire continental margin is unlikely to succeed as these rights were not recognized in the Geneva Convention of 1958.

There may be some question as to the relevance of international law to a domestic constitutional law dispute determining federal and provincial rights. However, the major writers and the jurisprudence, in their consideration of this question, address the international law implications. It was therefore felt that the present analysis would not be complete without an examination of those issues.

\section{CONSTITUTIONAL LAW ISSUES}

The importance of constitutional law to the case at bar is aptly stated by Professor Ivan Head: ${ }^{143}$

But international law, seeking as it does to make regular the relations among States (which, with certain international organizations are the only members of the international community) is incapable of articulating how the exercise of those sovereign rights is to be distributed among a number of competing repositories within a single state. That division is the exclusive concern of the municipal (domestic) constitutional law of the State. It is an internal contest. That is why the Court's ultimate decision, following its consideration and analysis of pertinent principles of international law, will be one of Canadian constitutional interpretation.

137. Id..

138. Supra n. 120 at 56.

139. Supra n. 119 at 382.

140. Supra n. 9 at 35.

141. Supra n. 8.

142. Supra n. 77 at 63.

143. Ivan Head, "The Legal Clamour Over Canadian Offshore Minerals" (1967) 5 Alta. L.Rev. $312,315$. 
The division of sovereign rights accrued under international law must be allocated between federal and provincial jurisdictions according to principles of domestic constitutional law, despite the fact that this legal framework was not designed for such a task. ${ }^{144}$

The British Columbia Reference gives an excellent indication of how existing principles of Canadian constitutional law might be applied to Newfoundland's claim to offshore resources. As emphasis was placed upon historical jurisdiction and the offshore rights brought by a province into Confederation, this can only strengthen Newfoundland's claim.

After the lands under the territorial sea were established as property in Canada, exclusive jurisdiction was easily found for Canada as against British Columbia. ${ }^{145}$ The Supreme Court of Canada found that British Columbia had no legislative jurisdiction since the lands under the territorial sea did not fall within any of the enumerated heads of s. 92, being outside the boundaries of the province. ${ }^{146}$ Canada could have been granted full rights either under s. 91(1A) (the Public Debt and Property) or under the residual power of s. 91.147 This was regarded as a matter affecting "the peace, order, and good government" (POGG) of Canada and as a s. 91 residual power. ${ }^{148}$

Newfoundland's counter-argument (to the s. 91 residual power argument) is s. 109 of the B.N.A. Act (all lands, mines, minerals and royalties . . belong to the Provinces). Newfoundland can distinguish her case on the basis of ownership of the offshore natural resources because they were within her boundaries prior to Confederation, and therefore can argue that these rights are protected by s. 109 .

In order to examine the purpose of s. 109 it is necessary to understand the circumstances of the Union of 1867. At that time natural resources were the primary source of provincial revenue, as opposed to the taxation powers of the Dominion. ${ }^{149}$ As natural resources were already owned by the provinces, the purpose was not to establish provincial title. Rather the section offered further protection of this source of provincial revenue against federal encroachment. A denial of provincial ownership unilaterally amends or repeals s. 109, which is not within the s. 91(1) federal power of amendment.

The real contest here is between s. 91 and s. 109 of the B.N.A. Act. This is very different than an issue between $\mathrm{s} .92$ and s. 91 powers since the provincial legislative powers are of secondary importance, such as in an issue of paramountcy. The key to the issue of provincial natural resources is the meaning that the courts will assign to "ownership" within s. 109. It has been argued that this provision protects the right of the provinces to control the release and production of the resources, ${ }^{160}$ and this is a s. 92(13) (Property

144. Supra n. 30 at 448.

145. Supra n. 12 at 375.

146. Id..

147. Id..

148. Id. at 376.

149. Rowland Harrison, "The Resources Question - Ownership, Taxation and Regulation Thereof". Speech given February 12, 1981, University of Alberta Law Centre, Edmonton, Alberta.

150. Id.. 
and Civil Rights) area as well. If the federal government were to expropriate these resources under the POGG concept of national concern or under the s. $92(10)(c)$ declaratory power, such an act would deny the provincial ownership protected by s. 109.

International law as a source of jurisdiction was argued in both the British Columbia Reference case and the Seas and Submerged Lands case as indicative that such jurisdiction was beyond provincial or state powers. It was held to be a matter of "POGG" in the former case and "external affairs" in the latter. The Seas and Submerged Lands Act of 1973 (Australia) was legislation with respect to external affairs, ${ }^{151}$ and as no class of subject entitled "external affairs" exists under the B.N.A. Act, the basis of the decision in the British Columbia Reference was POGG.

The POGG power was invoked using the national concern doctrine. The Supreme Court of Canada found that the mineral resources lying under the territorial sea adjacent to British Columbia were "of concern to Canada as a whole" and "go beyond local or provincial interests". ${ }^{132}$ As offshore mineral rights were characterized by their inherent nature as a matter of national concern, Parliament could assume jurisdiction over them.

Professor Joseph Arvay emphasizes the unfortunate implications of this finding: $:^{153}$

Nor would it be rational to distinguish between natural resources lying beneath the sea and those found inland. Oil is of the same importance regardless of its source. To single out natural resources lying beneath the sea but within provincial boundaries ... . as being of national concern would discriminate unfairly against the maritime provinces whose land is often barren and who look primarily to the sea for their livelihood and prosperity.

It is curious why this argument was made as it was not necessary to decide the British Columbia Reference case. If this argument was made simply to bar claims such as those of Newfoundland which could otherwise be distinguished on their facts, the result does not look promising for Newfoundland. It is submitted that this argument would not necessarily block Newfoundland's claim; it is not logical that oil is more important to a nation simply because it is under water.

A possible federal argument (not discussed in the British Columbia Reference) involves the declaratory power under s. 92(10)(c), whereunder the federal government can declare a local work to be for the general advantage of Canada and assume control. The question exists as to whether all oil and gas wells could be declared works for the general advantage of Canada, with the federal government taking control or acquiring federal ownership by expropriation. ${ }^{154}$ However, the province could argue that wells are not works, and that this power applies only to works and not to the resources themselves or the control of production.

After the Court in the British Columbia Reference case invoked the national concern doctrine, it continued (in the words of Professor Ivan Head) "for three further sentences which are so shocking in their impact, so far-

151. Supra n. 38 (New South Wales) at 474-475.

152. Supra n. 12 at 376.

153. J. Arvay, "Newfoundland's Claim to Offshore Mineral Resources: An Overview of the Legal Issues" (1979) 5 Can. Pub. Pol. 32 at 40.

154. Supra n. 149. 
reaching in their consequences and so totally out of keeping with the tone of the opinion to that point that one can only assume that the Court was not cognizant of what it was saying". ${ }^{155}$ The Supreme Court of Canada stated: ${ }^{156}$

Moreover, the rights in the territorial sea arise by international law and depend upon the recognition by other sovereign states. Legislative jurisdiction in relation to the lands in question belongs to Canada which is a sovereign State recognized by international law and thus able to enter into arrangements with other States respecting the rights in the Territorial Sea.

Canada is a signatory to the Convention on the Territorial Sea and the Contiguous Zone and may become a party to other international treaties and conventions affecting rights in the territorial sea. This language echoes the unsuccessful federal argument in the Labour Conventions case $^{157}$ that executive competence is not coexistent with legislative competence.

The decision of the Privy Council in the Labour Conventions case is expressed by Lord Atkin: ${ }^{168}$

For the purpose of ss. 91 and 92 , i.e. the distribution of legislative powers between the Dominion and the Provinces, there is no such thing as treaty legislation as such. The distribution is based on the classes of subjects; and as a treaty deals with a particular class of subjects, so will the legislative power of performing it be ascertained.

Here the Privy Council has established that executive competence is coextensive with legislative competence.

The Court in the British Columbia Reference has been criticized for taking this approach. However, considerable support for this position does exist. Professor Arvay notes that: ${ }^{158}$

The Labour Conventions case from which the Supreme Court of Canada departed was criticized by such eminent jurists as Ivan Rand (Rand, 1960) (former justice of the Supreme Court of Canada) and Lord Wright (Wright, 1955) who actually sat on the Privy Council during the Labour Conventions case.

In another recent decision, MacDonald v. Vapour Canada $L t d .{ }^{160}(1976)$, the Supreme Court of Canada suggested that the Labour Conventions case should be reconsidered. As the Labour Conventions case was not even addressed, much less distinguished, it is highly questionable whether this case has been overruled by this decision of the Supreme Court of Canada.

A strong federalist approach was taken in the Seas and Submerged Lands case where it was held that even if the Australian states had been independent nations with sovereign rights, on confederation these rights were lost as a necessary incident of federation. ${ }^{161}$ "This case wrongly interprets the British Columbia Reference as having the same ratio decidendi. ${ }^{162}$ Even if this approach is valid as a principle of law, this would not likely override the express language of Term 37 which preserves the natural resources owned prior to Confederation for Newfoundland. Arguably it would be necessary for Newfoundland to establish ownership of the seabed and subsoil rather than simply legislative jurisdiction over the territorial sea. ${ }^{163}$

155. Ivan Head, "The Canadian Offshore Minerals Reference" (1968) 8 U. Toronto L.J. 131 at 147.

156. Supra n. 12 at 376.

157. A.G. Can. v. A.G. Ont. [1937] A.C. 326.

158. Id. at $351-354$.

159. Supra n. 153 at 41.

160. MacDonald v. Vapour Canada Ltd. (1976)66 D.L.R. (3d) 1 at 24 (S.C.C.); supra n. 153 at 42.

161. Supra n. 38 (New South Wales) at 119.

162. Supra n. 25.

163. Id. at 490 . 
Newfoundland may be confronted with the alternative argument in the British Columbia Reference that federal control of the offshore is necessary because of federal foreign affairs responsibilities. ${ }^{164}$ Similar jurisdictional problems to those discussed in the Canadian British Columbia Reference case were addressed by the Tide-water cases in the United States Supreme Court. California, ${ }^{165}$ Texas, ${ }^{168}$ Louisiana ${ }^{167}$ and Main ${ }^{168}$ were each unsuccessful in claiming entitlement to the territorial waters adjacent to their coasts as against the federal government. The Supreme Court of Canada, echoing the decision of the United States Supreme Court in the California case, argued that, as only the federal government would be held responsible to other nations, federal control of offshore resources was required. This aspect of the British Columbia Reference has been criticized, ${ }^{169}$ for the Canadian federal government's powers to implement treaties are much more restricted than those of the American federal government. ${ }^{170}$

This interface of international law and constitutional law is addressed by Professor Ivan Head, as he speaks of the international consequences should British Columbia have been successful against Canada: ${ }^{171}$

Canada's sovereign prerogative for the conduct of foreign policy would be diminished considerably should the Supreme Court answer in favour of British Columbia the several questions in the Reference. A Pandora's box would be opened with the result that those provinces with seacoasts would be vested with a propensity for international activity bearing little semblance to Matters of a merely local or private nature in the Province'.

However, a decision recognizing that the property in the offshore is in Newfoundland is not precluded by the fact that Canada is now a sovereign state recognized by international law and able to enter into arrangements with other states respecting rights in the territorial sea and continental shelf.

Assuming the court would find that the territorial sea and continental shelf were part of the lands belonging to Newfoundland, this would not necessarily settle the jurisdictional issue. One possible arrangement would be to give Newfoundland primary jurisdiction over the management and sale (including leases) of the land and its natural resources pursuant to s. 92(5) (The Management and Sale of the Public Lands belonging to the Province and of the Timber and Wood thereon) or s. 92(13) (Property and Civil Rights in the Province). Canada could still discharge its international responsibilities even though property in the seabed would be vested in the province, as Parliament would retain its right to enact laws dealing with navigation and shipping (s. 91(10)), fisheries (s. 91 (12)), and defence (s. 91 (7)). Any conflict between a federal and provincial law would be resolved in favour of Parliament under the doctrine of paramountcy.

Principles of legal reasoning are not capable of a completely unambiguous application, ${ }^{172}$ and it is important to realize where "pure legal analysis ends

164. Supra n. 12 at 380.

165. United States v. California 332 U.S. 19 (1947).

166. United States v. Texas 339 U.S. 707 (1950).

167. United States v. Louisiana 339 U.S. 699 (1950).

168. United States v. Maine 43 L.W. 4359 (1975).

169. Supra n. 7 at $161 ;$ supra n. 87 at 559.

170. U.S. Const. art. V, 1 and 2.

171. Supra n. 155 at 327.

172. Neil Caplan, "Legal Issues of the Offshore Mineral Rights Dispute in Canada" (1968) 14 McGill L.J. 475 at 479. 
and value judgments . . . begin". ${ }^{173}$ Rival arguments in the British Columbia Reference often pointed to the same precedents as authority, as eleven out of a total of thirty authorities cited by British Columbia were also cited as authority for the federal government. ${ }^{174}$ In referring to this case, Neil Caplan states: ${ }^{175}$

Previous cases, then were unclear enough so that neither argument had to be favoured 'inevitably' by the Court. Faced with two equally plausible and internally consistent lines of reasoning, the Court chose to accept one completely (viz., that the realm ends at the low-water mark) and to reject the other as 'obsolete' (viz., that there is no difference between Crown lands above or below that mark in the three-mile zone).

This type of reasoning is evident where the Supreme Court ignored the Privy Council's rejection of Keyn in the Chelikani case. ${ }^{176}$ Despite the fact that Keyn is widely recognized as a source of judicial conflict, that case was adopted as the keystone of the British Columbia Reference decision. The Court did not even cite a former Supreme Court of Canada (1931) decision which accepted "as a well recognized principle that territorial waters within three miles of the shore are as clearly a part of the state as land". ${ }^{177}$ The failure to address these types of controversies has influenced many writers to characterize the Court's opinion as a policy decision in favour of federal jurisdiction over offshore areas based on foreign affairs responsibilities. ${ }^{178}$

It is submitted that unless a Newfoundland decision is based exclusively on the policy-oriented theory that foreign affairs responsibilities of Canada require federal control over the territorial sea and continental shelf, Newfoundland's claim will succeed. The unique historical circumstances of Newfoundland will favourably distinguish this situation from that of British Columbia in the British Columbia Reference. ${ }^{179}$ This implies that Newfoundland currently has legislative jurisdiction and ownership of the territorial sea and continental shelf.

\section{CONCLUSION}

The various results possible in the Newfoundland offshore mineral issue can be summarized as follows:

1. Newfoundland cannot establish sovereignty prior to Confederation by virtue of:

a. Non-application of the Statute of Westminster; or

b. Commission Government produced a loss of sovereignty, and

c. Term 7 did not revive sovereignty; or

d. Imperial legislation was necessary and lacking.

The result would then be that the common law (Keyn) applies because Newfoundland is in the same position as British Columbia was in the British Columbia Reference, meaning that Newfoundland would have no rights whatsoever in the offshore natural resources.

173. Leading Constitutional Decisions (P. Russell ed. 1965) xxiii.

174. Supra n. 172 at 481.

175. Id..

176. Supra n. 36 (Chelikani case) at 222.

177. The "May" v. The King [1931] S.C.R. 374 at 380.

178. Supra n. 7 at 162 ; supra n. 25 at 480,505 ; supra n. 172 at $479-80$.

179. Supra n. 25 at 489. 
2. Newfoundland can establish pre-Confederation sovereignty by virtue of:

a. The exercise of property and jurisdictional rights in relation to the territorial seas (continental shelf rights can not logically exist if territorial seas rights are absent), and

b. Imperial legislation; or

c. Chelikani case (Imperial legislation not necessary to establish rights in the territorial sea, meaning the Supreme Court of Canada reverses reliance on Keyn).

The result would be that:

a. Newfoundland possesses both property and jurisdictional rights in relation to the territorial seas, with Parliament retaining the right to legislate in areas such as navigation and shipping. Continental shelf rights (right to exploit and explore and jurisdiction) exist if they are established as accruing $a b$ initio or as a customary rule of law by 1949 ; or

b. Newfoundland has property rights only, with plenary jurisdiction in Parliament based upon POGG powers arising in the:

i. Subject matter outside of s. 92, or

ii. National concern doctrine, or

iii. International law source of jurisdiction; or

c. Newfoundland has neither property nor jurisdictional rights because:

i. Continental shelf rights were not a rule of customary international law by 1949 (only continental shelf rights are lost here), or

ii. Pre-Confederation status is irrelevant as a necessary attribute of federalism, or

iii. Foreign affairs responsibilities require federal control of both property and jurisdiction (policy decision).

3. Federal-provincial agreement is reached such as that with the other Maritime provinces ${ }^{180}$ or the Australian "mirror" legislation. ${ }^{181}$

180. Supra n. 4 ("Federal-Provincial Memorandum ....").

181. The agreement was implemented by identical Federal-State "mirror" legislation. See Petroleum (Submerged Lands) Act No. 118 of 1967 (Australia); and Petroleum (Submerged Lands) Act, No. 78 of 1967 (S. Australia) (representative state statute). 


\section{APPENDIX I \\ EXCERPTS FROM THE 1958 GENEVA CONVENTION \\ (CAME INTO FORCE JUNE 10, 1964)}

Article 1

For the purpose of these articles, the term "continental shelf" is used as referring (a) to the sea-bed and subsoil of the submarine areas adjacent to the coast but outside the area of the territorial sea, to a depth of 200 metres or, beyond that limit, to where the depth of the superjacent waters admits of the exploitation of the natural resources of the said area; (b) to the sea-bed and subsoil to similar areas adjacent to the coasts of islands.

\section{Article 2}

1. The coastal State exercises over the continental shelf sovereign rights for the purpose of exploring it and exploiting its natural resources.

2. The rights referred to in paragraph 1 of this article are exclusive in the sense that if the coastal State does not explore the continental shelf or exploit its natural resources, no one may undertake these activities, or make a claim to the continental shelf, without the express consent of the coastal State.

3. The rights of the coastal State over the continental shelf do not depend on occupation, effective or notional, or on any express proclamation.

4. The natural resources referred to in these articles consist of the mineral and other non-living resources of the sea-bed and subsoil together with living organisms which, at the harvestable stage, either are immobile on or under the sea-bed or are unable to move except in constant physical contact with the sea-bed or the subsoil.

\section{Article 3}

The rights of the coastal State over the continental shelf do not affect the legal status of the superjacent waters as high seas, or that of the airspace above these waters.

\section{Article 4}

Subject to its right to take reasonable measures for the exploration of the continental shelf and the exploitation of its natural resources, the coastal State may not impede the laying or maintenance of submarine cables or pipelines on the continental shelf.

\section{Article 5}

1. The exploration of the continental shelf and the exploitation of its natural resources must not result in any unjustifiable interference with navigation, fishing or the conservation of the living resources of the sea, nor result in any interference with fundamental oceanographic or other scientific research carried out with the intention of open publication.

2. Subject to the provisions of paragraphs 1 and 6 of this article, the coastal State is entitled to construct and maintain or operate on the continental shelf installations and other devices necessary for its exploration and the exploitation of its natural resources, and to establish safety zones around such installations and devices and to take in those zones measures necessary for their protection.

3 . The safety zones referred to in paragraph 2 of this article may extend to a distance of 500 metres around the installations and other devices which have been erected, measured from each point of their outer edge. Ships of all nationalities must respect these safety zones. 
4. Such installations and devices, though under the jurisdiction of the coastal State, do not possess the status of islands. They have no territorial sea of their own, and their presence does not affect the delimitation of the territorial sea of the coastal State.

5. Due notice must be given of the construction of any such installations, and permanent means for giving warning of their presence must be maintained. Any installations which are abandoned or disused must be entirely removed.

6. Neither the installations or devices, nor the safety zones around them, may be established where interference may be caused to the use of recognized sea lanes essential to international navigation.

7. The coastal State is obliged to undertake, in the safety zones, all appropriate measures for the protection of the living resources of the sea from harmful agents.

8. The consent of the coastal State shall be obtained in respect of any research concerning the continental shelf and undertaken there. Nevertheless, the coastal State shall not normally withhold its consent if the request is submitted by a qualified institution with a view to purely scientific research into the physical or biological characteristics of the continental shelf, subject to the proviso that the coastal State shall have the right, if it so desires, to participate or to be represented in the research, and that in any event the results shall be published.

\section{APPENDIX II \\ EXCERPTS FROM THE SCHEDULE OF TERMS OF UNION OF NEWFOUNDLAND WITH CANADA, BRITISH NORTH AMERICA ACT OF 1949, 12 AND 13 GEO. 6, C. 22 \\ Term 2}

The Province of Newfoundland shall comprise the same territory as at the date of Union, that is to say, the island of Newfoundland and the islands adjacent thereto, the Coast of Labrador as delimited in the report delivered by the Judicial Committee of His Majesty's Privy Council on the first day of March, 1927, and approved by His Majesty in His Privy Council on the twenty-second day of March, 1927, and the islands adjacent to the said Coast of Labrador.

\section{Term 7}

The Constitution of Newfoundland as it existed immediately prior to the sixteenth day of February, 1934, is revived at the date of Union and shall, subject to these terms and the British North America Acts, 1867 to 1946, continue as the Constitution of the Province of Newfoundland from and after the date of Union, until altered under the authority of the said Acts.

\section{Term 37}

All lands, mines, minerals, and royalties belonging to Newfoundland at the date of union, and all sums then due or payable for such lands, mines, minerals, or royalties, shall belong to the Province of Newfoundland, subject to any trusts existing in respect thereof, and to any interest other than that of the province in the same. 